\title{
MENGUSAHAKAN KEBAHAGIAAN DALAM KEGIATAN KERJA
}

\section{Paulus Wahana}

Universitas Sanata Dharma

Email: paulus_wahana@yahoo.com

\section{Abstrak}

Kerja merupakan kegiatan khas manusia, yang hanya dapat dilakukan oleh manusia, karena merupakan kegiatan yang disadari, perlu dipahami tujuan serta hasil yang diusahakannya. Kerja merupakan kegiatan yang memiliki tujuan serta hasil yang tentu saja dikehendakinya. Tujuan serta hasil yang diharapkan tentu saja merupakan hal yang bernilai bagi kehidupan manusia. Dan apabila hal yang bernilai tersebut terwujud tentu saja akan memberikan kebahagiaan bagi yang mengusahakannya, sebagai nilai pengiring yang menyertainya (bonum delectabile). Agar kegiatan kerja dapat memberikan kebahagiaan dalam kehidupan ini, maka perlulah orang menyadari akan adanya nilai-nilai yang dapat diwujudkan dalam kegiatan kerja. Sehingga kerja bukan lagi dilihat sebagai yang membebani dan melelahkan dalam kehidupan ini, melainkan dirasakan sebagai usaha mewujudkan nilai-nilai dalam kehidupan ini. Dengan menggali dan menemukan nilai-nilai yang kiranya termuat dalam kerja, serta memperjuangkannya demi terwujudnya nilai-nilai kerja, diharapkan dapat mewujudkan nilai-nilai kehidupan secara optimal. Tentu saja terwujudnya nilai-nilai kehidupan yang memang diperjuangkan dan diusahakan sebagai tujuan yang diharapkan akan memberikan kebahagiaan dalam kehidupan ini.

Kata kunci: kerja, nilai kerja, kebahagiaan

\section{Abstract}

Work is a typical human activity that can only be performed by humans. As it is a conscious activity, its purposes and results require understanding. Work is an activity with certain purposes and results which are expected. Those expected purposes and results of work are certainly valuable for human lives. When the valueable aspects of expected purpose are actualised into reality, it will certainly create happiness, as the accompanying value that comes along with it, for individuals who work for 
it (bonum delectabile). In order to enable activities of work creating happiness in this life, then we need to be aware of the existence of values that can be materialized in work activities. Work therefore will no longer be seen as burdensome and exhaustive human practise in this life. Rather, it will be perceived as a way to materialise the values of life. By exploring and searching for the values which are contained in work, and then struggling for the embodiment these values, it is expected that the embodiment values of life can be maximised. Of course, the embodiment values of life which are being fought for as the expected purpose of work activities will bring happiness in this life.

Keywords: work, work value, happiness

\section{PENDAHULUAN}

Berdasarkan kedudukan kodratnya, manusia merupakan makhluk yang paling luhur di antara makhluk-makhluk lainnya, sebagai makhluk yang memiliki otonomi, memiliki kebebasan dalam mengatur dan menentukan sikap dan arah hidupnya; menurut susunan kodratnya, manusia tidak hanya sekedar makhluk jasmaniah, tetapi juga merupakan makhluk rohaniah, yang memiliki daya cipta (kognitif), rasa (afektif), dan karsa (konatif). Sebagai makhluk yang paling luhur, manusia tidak hanya sekedar menerima serta bereaksi begitu saja terhadap keadaan yang dihadapinya, tetapi manusia mampu melakukan kegiatan yang lebih dari makhlukmakhluk lainnya. Kegiatan khas manusiawi tersebut merupakan kegiatan yang didasarkan pada kemampuan rohani manusia. Aktivitas khas yang dilakukan manusia tersebut berlangsung atas dasar perasaan, pemikiran, pertimbangan, pengambilan keputusan, dan selanjutnya adanya kehendak untuk mewujudkannya.

Dengan kelebihan ini, manusia diharapkan tidak berkedudukan sebagai objek, yang sekedar ditentukan dan menerima keberadaannya begitu saja, melainkan diharapkan berfungsi sebagai subjek, yang dapat menyadari, mempertimbangkan, memutuskan, dan menghendaki apa yang dilakukannya. Sehingga aktivitas yang dilakukan oleh manusia, 
diharapkan tidak sekedar muncul secara otomatis dari dorongan naluriah dalam dirinya, tidak hanya sekedar efek atau reaksi terhadap rangsangan atau stimulus yang mengenai dirinya, melainkan aktivitas yang dialami tersebut merupakan aktivitas yang disadari, dan dikehendakinya untuk diwujudkan. Kita manusia menyadari diri sebagai makhluk subjek yang otonom: mampu menyadari, menghendaki, dan membangun diri. (Bakker, 2000: 2327).

Dalam menghadapi lingkungannya, diharapkan manusia (sebagai subjek) sedapat mungkin mampu mengenang masa lampaunya, mampu berimajinasi, serta mampu melakukan pertimbangan, pemikiran, dan selanjutnya mengambil keputusan kehendak untuk bertindak mewujudkan apa yang memang dikehendakinya; menata dan mengatur dirinya serta hal-hal yang dihadapinya untuk dapat mewujudkan hal yang dianggapnya baik. Dan dalam menggunakan daya rohaninya tersebut, tentu saja diharapkan digunakan dengan benar dan menghasilkan keputusan bertindak untuk dapat mewujudkan hal yang dianggapnya baik tersebut. Menurut Stephen R. Covey (1989: 66-77) manusia diharapkan mampu mengembangkan daya rohaniahnya tersebut, sehingga manusia tidak menjadi objek atau korban keadaan, dan tidak bersifat reaktif terhadap keadaan, melainkan mampu berperanan sebagai subjek dalam menghadapi keadaan, dan bersifat pro-aktif, yang mampu merasakan, memikirkan, mempertimbangkan, dan akhirnya menghasilkan keputusan kehendak untuk menghadapi dan menangani dan menata keadaan tersebut sebagai peluang untuk mewujudkan kehidupan yang dikendakinya, lebih baik, lebih luhur, serta membawa kebahagiaan bagi hidupnya.

Selain daya cipta yang dapat membantu memberikan pemahaman yang jelas dan benar tentang berbagai hal dan masalah yang dihadapinya untuk diselesaikan, manusia juga memiliki kehendak atau kemauan bebas untuk dapat memilih tindakan yang mungkin dilakukannya. Sehingga selain pengetahuan, manusia juga 
memiliki kamauan untuk melakukan tindakan yang dipilihnya. Namun meskipun manusia memiliki kehendak bebas untuk memilih dalam bertindak, ternyata manusia tidak memilih dengan semenamena; dan justru karena tindakan tersebut disadari, maka manusia perlu mempertanggungjawabkan tindakannya untuk dapat mewujudkan hal yang baik dalam hidupnya (Makmurtono, 1989: hal. 23-24). Dalam rangka dapat mempertanggungjawabkan tindakannya tersebut, manusia dianugerahi daya rasa dalam hatinya, sebagai kesadaran yang selalu menyertai dirinya, yang menyadarkan manusia untuk bertindak baik dalam hidupnya dan menghindarai yang jahat (istilah bahasa Inggris conscience, istilah bahasa Latin conscientia). Sehingga pada saat manusia menghadapi masalah dan keadaan dalam hidupnya, manusia perlu merasakan, memikirkan dan mempertimbangkan yang ada dalam hatinya untuk mengambil keputusan bertindak didasarkan pada landasan bahwa manusia wajib melakukan tindakan yang baik, dan menghindari yang jahat, dalam rangka mewujudkan nilai-nilai; dan dengan demikian dapat mewujudkan kedamaian bagi hidupnya, memperoleh ketenangan, kepuasan dan kebahagiaan bathin (bonum delectabile).

Dengan tindakan-tindakan yang secara khas dilakukan oleh manusia tersebut, manusia berusaha mencapai tujuan yang diharapkannya. Dan pada saat melakukan tindakan-tindakan yang baik, serta dapat mewujudkan nilai-nilai yang menjadi tujuan yang diharapkan, sebagai dampaknya manusia dapat merasakan nilai kesenangan atau kebahagiaan dalam hidupnya (bonum delectabile). Ada berbagai kegiatan yang dilakukan oleh manusia untuk dapat mewujudkan nilai-nilai yang menjadi tujuan yang diharapkan, serta dapat memberi kesenangan, kepuasan, dan kebahagiaan. Salah satu kegiatan yang dapat dilakukan oleh manusia untuk mencapai tujuan dan kebahagiaan hidupnya adalah kegiatan kerja. Dalam artikel ini penulis bermaksud membahas bagaimana manusia dapat mengusahakan dan memperoleh kebahagiaan dalam melakukan kegiatan kerja. Setelah membahas tentang kecenderungan 
kehidupan manusia untuk mewujudkan tujuan-tujuan hidupnya yang kiranya memuat nilai-nilai yang dapat memberikan kebahagiaan hidupnya, selanjutnya akan membahas tentang kegiatan kerja yang merupakan kegiatan khas manusia yang kiranya dapat mewujudkan berbagai macam nilai yang dapat memberikan kebahagiaan dalam hidup manusia. Dengan demikian diharapkan orang dapat menyadari dan merasakan bahwa kerja bukan hal yang membebani dan bahkan menyengsarakan hidupnya, melainkan merupakan kegiatan yang dapat memperkaya dan mendatangkan kebahagiaan bagi manusia.

\section{KEHENDAK MENUJU KEBAHAGIAAN}

Dalam beraktivitas, manusia dipengaruhi oleh dua hal, yakni dari dalam dirinya ada pengaruh dari dorongan/kebutuhan naluri/instink biologis, dan dari stimulus yang berasal dari luar dirinya, yaitu pengaruh dari lingkungan alam maupun lingkungan sosial. Berbeda dengan binatang, manusia yang akal-budi (kesadaran) dan kehendak bebasnya berfungsi dengan baik, dimungkinkan untuk mengambil jarak dan bahkan mengatur dan memanfaatkan ketentuan dua pengaruh tersebut menjadi peluang dalam mendukung mewujudkan kehendaknya, sehingga dalam bertindak dia lebih dapat dengan bebas menghendaki serta menentukan apa yang menurut kesadarannya sendiri sebaiknya atau sepantasnya ia lakukan; dua pengaruh tersebut tidak mengurangi atau bahkan menghilangkan kebebasan manusia dalam mewujudkan kehendaknya, melainkan justru dapat menantang, dapat menjadi peluang, serta dapat dimanfaatkan manusia dalam mendukung mewujudkan kehendaknya. Misalnya lingkungan alam yang dihadapinya, pada awalnya manusia merasakan lautan merupakan hambatan bagi perjalanan hidup manusia, merupakan monster, karena dapat menenggelamkan dan mematikan dirinya, namun selanjutnya manusia mampu menghadapi serta mengatur lingkungan tersebut, dan justru dapat dimanfaatkan sebagai peluang 
dan sarana transportasi alternatif bagi perjalanannya, dan bahkan menjadi sarana berekreasi (main selancar, snoorcling, diving, dll.).

Binatang tidak dapat mengambil jarak dari desakan naluriahnya dan pengaruh (stimulus) dari luar dirinya, karena binatang tidak memiliki kesadaran / akal budi untuk mengerti dan mempertimbangkan baik-buruknya perbuatannya, dan tidak memiliki kehendak bebas untuk menentukan/memilih apa yang dikehendakinya. Binatang selalu mengikuti arah naluri/instink biologisnya yang sudah terprogram dengan sistem kendali tertentu, binatang memberikan reaksi tertentu yang telah terpolakan terhadap stimulus yang dihadapinya. Jika seekor kucing sedang lapar dan di depannya disodorkan ikan, maka tanpa basa basi ia akan langsung menyantapnya, tetapi jika sudah kenyang ia akan meninggalkan sisanya. Binatang semata-mata dikendalikan atau diarahkan oleh dorongan instink/naluriahnya (misal: naluri untuk mempertahankan hidupnya, melindungi diri, dorongan untuk berkembang biak), dan stimulus dari luar dirinya. Maka, perilaku binatang itu dapat kita pelajari, prediksi, dan manipulasi seperti halnya kita memanipulasi gerak-robot, sehingga dapat dihasilkan perilaku binatang sebagaimana diinginkan manusia, seperti sering ditampilkan dalarn sirkus.

Sedangkan meskipun perilaku manusia dapat diprediksi dan dimanipulasi dengan diberi kondisi-kondisi tertentu, namun ia tetap mempunyai kebebasan untuk mengambil jarak dan pilihan terhadap kondisi-kondisi tersebut dan bertindak sesuai dengan kesadaran dan pilihan kehendaknya sendiri. Dalam tindakan khasnya, manusia selalu berada di dalam kebebasannya. Akal budi, hati nurani, dan kehendak bebas manusia menjadi kendali utama dalarn berperilaku. Oleh adanya akal-budi, hati nurani, dan kehendak bebas ini, manusia disebut makhluk yang bermartabat, paling tinggi (luhur) di antara segala makhluk hidup lainnya. Unsur-unsur tersebut menjadi kekhasan kodrat manusiawi manusia.

Hal ini mengandung konsekuensi bahwa untuk mewujudkan kepenuhan kemanusiannya, manusia mesti mempergunakan nurani 
dan akal budinya untuk mempertimbangkan baik/buruknya dan dampak perbuatan yang hendak ia lakukan, dan mempergunakan kebebasan kehendaknya untuk menentukan/memilih, dan menghendaki perbuatannya sesuai dengan pertimbangan budi dan nuraninya. Meskipun manusia memiliki kebebasan dalam menentukan sikap dan relasi terhadap dirinya, terhadap lingkungannya, namun manusia ternyata tidaklah bertindak semena-mana, malainkan memiliki keterarahan ke kehidupan yang bernilai, kehidupan yang bermutu, kehidupan yang bermartabat. Arah kodrat khas manusiawinya mengharuskan/ mewajibkan dia menghendaki dan melaksanakan tindakan-tindakan yang menyempurnakan dirinya dan sesamanya, dalam rangka mewujudkan nilai-nilai yang dapat memberikan kebahagiaan bagi hidupnya (Wahana, 2004: 55-56).

\section{KEGIATAN KERJA}

Sebelum membahas kegiatan kerja yang dapat mewujudkan kebahagiaan, ada baiknya menentukan terlebih dahulu apakah yang dimaksud kegiatan kerja. Bila kita memperhatikan ungkapan orang tentang istilah kerja, ternyata memiliki pengertian yang bermacammacam. Dari lingkup pengertian yang sangat luas, yang memasukkan segala kegiatan yang dapat dilakukan manusia, ke pengertian yang semakin sempit, sampai dengan kegiatan yang dibatasi berbagai macam syarat. Misalnya, sebagai pengertian yang paling luas, kita biasa mendengarkan ungkapan: "Orang kok pekerjaannya hanya tidur saja, hanya jalan-jalan, hanya dudukduduk, hanya melamun saja". Ini berarti segala macam kegiatan yang dilakukan manusia dapat digolongkan dalam pengertian kerja. Sementara ada yang mengatakan bahwa seorang ibu tidak kerja, hanya di rumah saja; pada hal bila diperhatikan ibu tersebut melakukan berbagai macam hal (kegiatan kerja), bahkan sejak dari bangun pagi hingga mulai meninggalkan kegiatan sehari-hari pergi ke tempat tidur. Ada juga orang mengatakan "Sejak memperoleh gelar sarjana, dia sampai sekarang belum kerja; hanya melakukan 
kegiatan gotong-royong, melakukan kegiatan pengabdian masyarakat, yaitu misalnya: melakukan bimbingan belajar bagi anak-anak miskin". Ini berarti yang dapat dimasukkan ke dalam pengertian kegiatan kerja adalah hanya kegiatan yang diberikan upah atau imbalan. Sehingga segala kegiatan, meskipun memberikan hasil yang bermanfaat, berupa barang atau jasa, namun karena tidak memperoleh upah atau imbalan, maka kegiatan tersebut tidak dapat dimasukkan ke dalam pengertian kerja. Sehingga kiranya perlu ditentukan kegiatan-kegiatan mana yang kiranya dapat termasuk kerja: apakah segala kegiatan yang dilakukan manusia, apakah segala kegiatan yang menghasilkan, atau apakah hanya kegiatan yang memperoleh upah atau imbalan saja?

Maka baiklah kita membuat batasan pengertian tentang kerja, sehingga jangan sampai yang semestinya bukan termasuk kerja dimasukkan, atau sebaliknya yang semestinya termasuk kegiatan kerja tidak dimasukkan sebagai kegiatan kerja. Pembatasan pertama yang dapat kita lakukan adalah bahwa yang termasuk dalam kegiatan kerja adalah kegiatan yang secara khas hanya dapat dilakukan oleh manusia. Sehingga berbagai kegiatan yang berlangsung di luar diri manusia tidak dapat kita masukkan dalam kerja. Misalnya: kegiatan gunung berapi yang dapat menghasilkan berbagai macam bahan bangunan tidak dapat dikatakan sebagai kegiatan kerja; meskipun kerbau dengan susah payah menarik bajak dalam kegiatan membajak, namun yang melakukan kerja membajak adalah manusia, sedangkan kerbau tidak dapat dikatakan melakukan kegiatan kerja, hanya sebagai alat bantu bagi manusia dalam kegiatan kerja. Kedua, tidak sembarang kegiatan yang dilakukan oleh manusia adalah kerja, namun hanya kegiatan khas manusia yang disadari dan dikehendaki serta memberikan hasil dapat dimasukkan dalam kegiatan kerja. Ketiga, juga tidak sembarang kegiatan khas manusia yang disadari dan dikehendaki serta memberikan hasil termasuk dalam kegiatan kerja, namun merupakan tindakan khas manusia yang memberikan hasil secara objektif terpisah dari pelaku dan dapat juga dirasakan dan berguna 
bagi yang lain; hasilnya dapat berupa barang atau jasa. Orang yang berolah raga, orang yang makan, tidak dapat dikategorikan bahwa orang-orang tersebut melakukan kegiatan kerja. Meskipun kegiatan tersebut dapat menghasilkan keringat, dapat menghasilkan rasa kenyang, tetapi hasil-hasil tersebut bukan merupakan hasil objektif yang dapat juga digunakan yang lain. Dengan langkah-langkah pembatasan tersebut, kiranya kita dapat menemukan batasan pengertian kerja sebagai kegiatan yang dilakukan manusia, sebagai kegiatan khas manusia (yang disadari dan dikehendaki, serta memiliki tujuan), dan memberikan hasil objektif yang memang menjadi tujuannya (Soerjanto \& Bertens, 1978: 74). Adapun hasil dari kegiatan kerja yang dilakukan oleh manusia, dapat berupa barang, dan dapat juga berupa jasa. Contoh kegiatan kerja yang menghasilkan barang, misalnya: kegiatan kerja petani yang dapat menghasilkan padi, jagung; kegiatan kerja nelayan yang dapat menghasilkan ikan hasil tangkapannya. Contoh kegiatan kerja yang menghasilkan jasa, misalnya: kegiatan kerja tukang pos yang dapat menghasilkan / memberikan jasa mengantarkan barang atau surat dari pengirim ke pihak yang dikirimi; kegiatan kerja sopir taksi yang dapat menghantarkan penumpang dari tempat asal ke tempat yang menjadi tujuannya.

Kegiatan kerja itu hanya muncul dalam kehidupan manusia, karena di satu pihak manusia mempunyai kebutuhan untuk mempertahankan dan mengembangkan kehidupannya, namun di lain pihak belum tersedia begitu saja yang dapat langsung digunakan dalam alam ciptaan ini. Sementara makhluk hidup ciptaan lainnya (tumbuh-tumbuhan, binatang) sudah memiliki kemampuan memenuhi kebutuhan bagi hidupnya dari alam lingkungan di sekitarnya. Bunga-bungaan sudah memperoleh keindahan dengan sendirinya, meskipun mereka tidak harus mempercantik diri. Burung-burung di udara tidak harus bersusah payah menabur benih dan menanam, namun mereka sudah dapat segala biji-bijian atau buah-buahan yang dapat menjadi makanannya di alam ini. Segala binatang telah memiliki kelengkapan yang 
mencukupi untuk mempertahankan dan melindungi diri dari berbagai serangan cuaca dan musim, atau serangan dari makhluk lainnya, dengan menggunakan kulit, bulu, sisik, taring yang sudah melekat dalam dirinya. Tumbuh-tumbuhan, binatang telah memiliki kelengkapan pada dirinya untuk dapat beradaptasi dan mempertahankan diri dalam melangsungkan kehidupannya. Sedangkan manusia secara fisik, tidak memiliki kelengkapan yang memadai untuk memperoleh makanan dan perlindungan diri dalam menghapi lingkungan sekitar.

Namun manusia memiliki kemampuan dan kemauan melakukan kegiatan kerja mengubah dan mengolah alam menjadi sarana dan alat yang dapat membantu untuk memenuhi kebutuhan hidupnya, untuk mempertahankan dan mengembangkan dirinya. Batu, perunggu, dan selanjutnya logam dapat dikerjakan oleh manusia, diolah menjadi peralatan yang dapat membantu manusia mempermudah memperoleh bahan-bahan makan bagi kehidupannya, dan dapat membanntu manusia mempertahankan diri dalam menghadapi lingkungan hidup sekitarnya. Kegiatan kerja dapat mengubah dan menciptakan lingkungan alam yang alamiah menjadi lingkungan yang bermanfaat bagi kehidupan manusia, yang dapat diperalat manusia; dan sebaliknya untuk mewujudkan lingkungan yang berfaedah diperlukan / dituntut adanya ketersediaan, kesiapan, dan kemampuan manusia untuk dapat mengolahnya serta memanfaatkannya (Kwant, 1960: 6-9).

Kegiatan kerja yang disadari dan dikehendaki untuk memperoleh hasil tentu saja memerlukan pemikiran. Pemikiran ternyata bermanfaat bagi manusia untuk memberikan dasar pertimbangan dan arah dalam bertindak; menentukan jalan, sarana, serta cara manusia dalam pelaksanaannya, agar mencapai hasil yang memang menjadi tujuan manusia dalam kegiatan kerja. Kegiatan kerja memang merupakan keistimewaan bagi makhluk yang berakaal budi. Manusia memiliki kesadaran dan kehendak bebas untuk mengarahkan kegiatannya kepada suatu tujuan yang telah ditentukannya (Groenen \& Lanur, 1985: 28-29). 
Ada berbagai macam bidang yang menjadi kebutuhan dalam hidup manusia, maka banyak pulalah bidang kegiatan kerja yang dapat dilakukan oleh manusia, misalnya: bidang pertanian, peternakan, perkebunan, perikanan, perumahan, kesehatan, transportasi, hiburan, perindustrian, ketertiban, keamanan, pendidikan. Selaras dengan perkembangan kebutuhan dalam hidup manusia, berkembang pula kemampuan dalam kegiatan kerja manusia. Misalnya dalam bidang pangan, manusia ternyata memiliki kebutuhan yang berkembang, yang tiidak hanya sekedar mengisi perut dan kenyang, tetapi mempunyai kebutuhan untuk memperoleh makanan yang semakin memiliki rasa yang lezat, makanan yang semakin menyehatkan, dan dalam kerjanya muncul pemikiran dan usaha bagaimana dapat dikerjakan agar makanan dapat semakin lezat, dan bagaimana dapat dikerjakan agar makanan dapat semakin menyehatkan; dalam bidang transportasi orang semakin memiliki kebutuhan agar transportasi dapat semakin lancar, semakin nyaman, semakin mampu menjelajah ke seluruh dunia, maka manusiapun melakukan kegiatan kerja yang dapat memberikan sarana transportasi sebagaimana dibutuhkan manusia.

Sebagai kegiatan yang perlu dipikirkan, direncanakan, serta dilaksanakan, maka kegiatan kerja juga ada bagian yang memikirkan, merencanakan, serta melaksanakan. Macam-macam kegiatan kerja dapat terbentang dari kegiatan yang bersifat teoritis, hingga kegiatan yang praktis. Sehingga dalam memahami kegiatan kerja secara lengkap, tentu saja kita perlu melihatnya secara utuh, sebagai kegiatan kerja bersama manusia, dalam rangka mewujudkan hasil yang berupa barang atau jasa. Dengan adanya berbagai macam bidang, dan bagian dalam kegiatan kerja manusia, diharapkan kebutuhan hidup manusia yang bermacam-macam dan semakin berkembang tersebut juga dapat saling dibantu untuk dipenuhi.

\section{NILAI-NILAI DALAM KERJA}

Dari pembahasan di atas, dapat kita ketahui bahwa kegiatan kerja memang memberikan hasil berupa barang atau jasa sebagai 
tujuannya. Kegiatan kerja manusia dapat menghasilkan barang yang memang dapat memenuhi kebutuhan hidup manusia, kebutuhan primer (sandang, pangan, dan papan), kebutuhan sekunder (sarana yang mendukung untuk memperoleh barang pemenuhan kebutuhan primer, yaitu alat untuk mendukung kegiatan berproduksi), maupun kebutuhan tersier (yaitu kemewahan yang dapat memberikan kenikmatan pada manusia, misalnya $t v$, radio, ac, dll). Sedangkaan kegiatan kerja yang menghasilkan jasa, misalnya kerja pedagang yang mengantarkan barang dari sumbernya ke konsumen, kerja tukang ojek yang mengantarkan orang dari suatu tempat ke tempat tujuan, kegiatan kerja hiburan, wisata. Hasil barang serta jasa yang memang dapat memenuhi kebutuhan hidup manusia dapatlah dikatakan memberikan hasil ekonomi. Dan berhubung memberikan hasil (barang atau jasa) yang dapat memenuhi kebutuhan hidup orang lain, maka sudah selayaknya memperoleh imbalan / upah dari orang lain yang berupa barang atau uang. Dan barang atau uang tersebut, sebagai imbalan, dapat digunakan orang bersangkutan untuk memenuhi kebutuhan hidupnya. Sehingga boleh dikatakan kegiatan kerja memuat nilai ekonomi, karena secara langsung ataupun tidak langsung pekerja akan menghasilkan barang atau uang (sebagai imbalan) yang dapat dipakai untuk memenuhi kebutuhan hidup manusia.

Selain memuat nilai ekonomi yang kiranya bermanfaat dapat memenuhi kebutuhan hidup manusia, kiranya kita perlu melihat lebih mendalam dan lebih lengkap tentang nilai-nilai yang kiranya dapat kita temukan dalam kegiatan kerja. Untuk dapat melakukan kegiatan kerja yang menghasilkan barang atau jasa, kiranya orang perlu mimiliki kemauan dan kemampuan sebagai modal yang mencakup niat, kemampuan fisik, intelektual, maupun ketrampilan. Sebelum dapat melakukan kegiatan kerja, secara formal ataupun tidak formal sering orang perlu balajar, melakukan persiapan atau pelatihan untuk dapat memberikan hasil yang diharapkan. Sehingga orang memiliki modal kemauan dan kemampuan untuk dapat melakukan kegiatan kerja. Dan selanjutnya dengan melakukan 
kegiatan kerja tersebut, diharapkan kemauan serta kemampuannya tidak berkurang, tetapi diharapkan kerja justru dapat memupuk dan mengembangkan kemauan serta kemampuannya. Orang diharapkan dapat belajar dan mengembangkan kemauan dan kemampuannya melalui kegiatan kerja (learning by doing). Dari uraian tersebut kiranya jelaslah bahwa kegiatan kerja dapat mengembangkan secara menyeluruh orang yang melakukan kegiatan kerja; mengembangkan kecintaan hatinya pada kerja yang ditekuni serta kepekaan dan kepeduliaannya terhadap kehidupan yang semakin bernilai (conscience dan compassion), mengembangkan kemampuan dan kecerdasan pemikiran dalam menghadapi masalah-masalah dalam kerjanya, serta mengembangkan ketrampilan dalam melaksanakan kegiatan kerja (competence). Dengan demikian berarti kegiatan kerja tersebut memiliki nilai pengembangan diri.

Melalui kegiatan kerja, orang sebenarnya bersama Sang Pencipta ikut serta dalam karya penciptaanNya. Allah terlebih dahulu telah menciptakan alam semesta dengan segala isinya, dengan segala aktivitas serta keteraturannya, dan disediakan sebagai sarana bagi pemenuhan kebutuhan hidup manusia. Dan manusia, sebagaimana tertulis dalam kitab suci, memiliki tugas untuk menata, mengolah, dan kemudian baru menggunakan untuk pemenuhan kebutuhan hidupnya. Sebagai yang memiliki tugas untuk menata, mengolah, dan menggunakannya, tentu saja manusia perlu mempelajari bagaimana Allah telah mengatur/menata alam ini sesuai hukum-hukum (alam) yang telah ditentukanNya, untuk lebih lanjut dapat ikut berkarya, ikut mencipta yang selaras juga dengan tatanan (hukum alam) yang telah ditentukan. Selain perlu mempelajari bagaimana alam ini tertata dan bagaimana perlu ditata dan diolah lebih lanjut, tentu saja perlu diingat bahwa penataan dan pengolahan itu diharapkan memang juga sesuai dengan kehendak Allah, yaitu demi menghasilkan dan menyediakan hal yang kiranya bernilai, berguna untuk memenuhi kebutuhan hidup manusia. Dari uraian tersebut kiranya nampak jelas bahwa kerja merupakan kegiatan untuk ambil bagian dalam karya penciptaan Allah, demi 
lebih tersedianya hal-hal untuk pemenuhan kebutuhan hidup manusia yang memang sesuai dengan tatanan serta kehendak Allah. Dengan demikian dapat dikatakan melalui kegiatan kerja, manusia dapat mewujudkan nilai religius, yaitu ikut serta mewujudkan kebaikan yang dikehendaki Allah, serta menghindari kejahatan yang memang dilarang oleh Allah. Dengan demikian selain mewujudkan nilai religius, juga mewujudkan nilai moral, karena orang dalam kegiatan kerja diharapkan mewujudkan nilai positif yang dibutuhkan, dan menghindari nilai negatif yang perlu dihindari manusia, yaitu menghindari kegiatan perusakan / penghancuran terhadap hal-hal yang telah tercipta dan terbangun sesuai dengan kebutuhan hidup manusia. Sesuai dengan Etika Nilai Max Scheler, diharap pekerja semakin terdorong untuk mewujudkan nilai-nilai positif, dan menghindari nilai-nilai negatif dalam kegiatan kerjanya (Wahana, 2016: hal 201)

Dari penjelasan di atas juga nampak bahwa kegiatan kerja bukanlah kegiatan manusia yang hanya semata-mata mencari manfaat atau keuntungan bagi dirinya sendiri, melainkan kegiatan yang diharapkan memberikan hasil positif (barang atau jasa) yang kiranya dapat membantu kehidupan manusia (baik dirinya sendiri maupun orang lain) dalam memenuhi kebutuhan hidupnya. Selain dapat memenuhi kebutuhan hidupnya sendiri, sebagai makhluk sosial, ternyata sangat dimungkinkan melalui kegiatan kerja manusia semata-mata membantu / memberikan barang atau pelayanan pada yang lain, melalui kegiatan kerja orang melakukan kerjasama satu sama lain, melalui kegiatan kerja orang dapat saling memberikan dan menerima hasil yang telah mereka usahakan. Dengan kegiatan kerja nampak orang berinteraksii satu sama lain, peduli terhadap orang lain, saling memberikan bantuan pada yang membutuhkan, saling memberikan pelayanan pada yang lain, mewujudkan kerjasama dalam rangka menghasilkan hal yang menjadi kebutuhan bersama. Melalui kegiatan kerja, dapatlah diketahui bahwa manusia ternyata saling berinteraksi satu sama lain sebagai socius (teman), juga mewujudkan nilai sosial dalam 
kehidupan ini, dalam rangka saling memenuhi kebutuhan satu sama lain, saling memperlancar, saling memperingan dalam menjalani kehidupan ini.

\section{MENGUSAHAKAN KEBAHAGIAAN DALAM KERJA}

Dari penjelasan di atas dapat kita ketahui bahwa arah tujuan hidup manusia adalah memperoleh kebahagiaan. Dan kebahagiaan dapat dirasakan sebagai akibat, apabila orang telah berhasil dapat mewujudkan hal-hal yang bernilai, yang menjadi tujuan dalam usaha yang dilakukannya, bahkan pada saat manusia baru mewujudkan sarana-sarana bagi terwujudnya nilai-nilai yang sesungguhnya. Kegiatan kerja ternyata bukan sekedar melakukan kegiatan yang melelahkan, kegiatan yang membebani, kegiatan yang menyengsarakan, melainkan merupakan kegiatan yang menjadi sarana dan cara manusia untuk mewujudkan hal-hal yang bernilai, yang memang diharapkan dan menjadi tujuan dari kegiatan yang dilakukannya. Namun sayang, kadang-kadang orang dalam melakukan kegiatan kerja hanya menyadari akan akibat yang melelahkan, serta adanya upah sebagai imbalan yang mungkin dianggap sedikit. Dengan demikian hal ini tentu saja tidak akan memberikan kepuasan atau kebahagiaan bagi orang bersangkutan. Akibatnya orang juga bermalas-malas dalam kerja, hasil kerjanya tentu saja juga semakin sedikit, demikian pula imbalan yang diperoleh dengan sendirinya akan sedikit pula. Sehingga untuk memberikan kepuasan atau kebahagiaan lebih, kiranya orang tersebut perlu memiliki kesadaran akan hasil-hasil kerja yang ternyata memiliki nilai-nilai yang kiranya layak dibanggakan dan dapat memberikan penghiburan dan kebahagiaan bagi hidupnya. Untuk dapat memperoleh kebahagiaan dalam kerja, kiranya perlu orang memahami dan menyadari akan betapa penting dan bernilainya kerja yang dilakukan oleh manusia.

Dengan menyadari betapa penting dan bernilainya kerja, kiranya orang dapat bersikap dan menjalani kegiatan kerja dengan benar dan baik pula. Berhubung kegiatan kerja itu merupakan 
kegiatan khas manusia dan bukan kegiatan yang berjalan secara otomatis, maka dalam menjalani kegiatan kerja perlu memiliki sikap moral yang positif dan baik, kerja perlu diusahakan dengan sungguh-sungguh, perlu menggunakan segala kemampuan yang relevan dan yang kita miliki, perlu mempertimbangkan dengan sebaik-baiknya, serta dilakukan dengan serius dan teliti, agar memberikan hasil yang optimal, hasil yang sungguh berkualitas. Dengan penggunaan segala kemampuan relevan yang kita miliki, berarti kita berlatih menerapkan / mempraktikkan kemampuan yang kita miliki, sehingga diharap kita dapat mengembangkan diri secara optimal pula dalam kegiatan kerja tersebut. Dengan kerja yang sungguh-sungguh diharapkan kita memiliki keuntungan ganda, yaitu dapat mengembangkan diri kita melalui pengalaman praktik kerja secara optimal, serta memberikan hasil kerja yang memiliki kualitas yang optimal pula. Dan bagi orang yang menerima hasil kerja tersebut tentu saja akan memberikan penghargaan yang tinggi, dan dengan demikian diharapkan memberikan imbalan yang besar pula. Dan dengan hasil yang memberikan keuntungan ganda tersebut tentu saja akan mendatangkan kebahagiaan yang besar pula dalam kerja.

Berhubung kerja merupakan kegiatan khas manusia, maka pekerja perlu menyadari dan memikirkan tentang kegiatan kerja yang dilakukannya. Meskipun hanya sekedar pelaksana dalam kegiatan kerja, pekerja tetap memiliki tanggungjawab bagi tercapainya tujuan kegiatan kerja tersebut. Dia perlu memahami tujuan yang akan / wajib dicapai dalam kegiatan kerja yang dilakukannya itu, sehingga masih perlu mempertimbangkan segala strategi dan teknik yang sesuai bagi keberhasilan dalam mencapai tujuan kerja tersebut. Maka seluruh pekerja yang terlibat perlu diajak memahami arah tujuan kegiatan bersama yang dilakukan, serta tanggung-jawab masing-masing bagiannya. Sedangkan terkait dengan sarana dan prasarana kerja, meskipun memiliki daya yang melebihi daya manusia, namun tetap memiliki kedudukan di bawah pelaksana kegiatan kerja. Sarana dan prasarana kerja merupakan 
peralatan yang diharap membantu dan mempermudah kegiatan kerja manusia, maka pekerja perlu menguasainya dalam kegiatan kerja (Beding, 1978: 25-27).

Selain kita perlu memiliki kesadaran yang benar tentang kerja, serta sikap yang positif atau baik terhadap kerja, kiranya kita perlu juga mengusahakan berbagai hal yang terkait agar dapat memberikan dukungan secara optimal bagi terselenggaranya kegiatan kerja, sehingga menghasilkan hasil yang optimal juga. Karena kegiatan kerja kita selalu berada dalam lingkungan kerja (baik lingkungan sosial maupun lingkungan fisik), maka kita perlu menciptakan lingkungan sosial kerja yang kondusif, saling kerja sama, saling mendukung, saling membantu satu sama lain, dalam rangka mendukung bagi terwujudnya hasil serta nilai kerja yang optimal. Dalam kegiatan kerja, diharap kita tidak memperlakukan yang lain sebagai objek, memperalat yang lain hanya sekedar sebagai sarana produksi, atau bahkan dianggap sebagai penghalang, namun diharapkan memperlakukan satu sama lain sebagai subjek, yang mampu mempertimbangkan, memiliki perasaan, serta memiliki kehendak dalam bertindak. Dengan perlakuan terhadap pekerja sebagai subjek yang bebas dan otonom, diharapkan pekerja mampu mempertanggungjawabkan kerjanya, serta mengusahakan kegiatan kerja secara berkualitas.

Berhubung kegiatan kerja adalah berusaha bersama menghasilkan barang atau jasa demi mencukupi kebutuhan hidup bersama manusia, maka selayaknya dalam melakukan kegiatan kerja kita perlu mencipkan lingkungan kerja bersama yang saling mendukung, saling memberikan semangat dalam kegiatan kerja, Kita perlu menyadari tempat dan bagian masing-masing dalam kerja, dan diharapkan dapat melakukan kegiatan kerja seuai bagiannya secara optimal, sehingga diharapkan dapat menyumbangkan kehidupan yang semakin bernilai secara optimal pula. Kita perlu menghargai peranan pekerja-pekerja secara adil, jangan sampai memandang pekerja satu lebih rendah dari pada lainnya, sehingga setiap pekerja memiliki harga diri dan semangat 
kerja dalam mendukung kehidupan yang semakin bernilai. Dan dengan demikian diharapkan masing-masing pekerja dapat memberikan sumbangan sesuai bagian dan kemampuannya secara optimal, dan secara sinergi kita dapat saling membantu kerjasama dalam mewujudkan kehidupan yang semakin bernilai.

Selain lingkungn sosial, kita perlu juga menciptakan lingkungan fisik yang mendukung kegiatan kerja, sedapat mungkin mengusahakan sarana atau alat kerja yang memang dapat membantu dan mendukung untuk memperlancar serta memperingan kegiatan kerja yang kita lakukan. Sehingga dengan menggunakan sarana kerja, diharapkan manusia dalam melakukan kegiatan kerja tidak harus memeras keringat dan membanting tulang, tetapi dengan dengan mennggunakan sarana kerja tersebut secara bertanggungjawab dapat menghasilkan barang atau jasa secara optimal. Selain sarana kerja yang mendukung, kitanya perlu mengusakahan lingkungan fisik tempat kerja yang nyaman, sehat. Sehingga tempat kerja diharapkan bukan dirasa sebagai penjara atau bahkan neraka yang perlu dihindari oleh setiap pekerja, tetapi diharapkan menjadi tempat yang nyaman, dan membuat orang krasan dalam melakukan kegiatan kerja. Dan rasa nyaman dan krasan tersebut diharapkan dapat mendukung terciptanya energi yang positif untuk mendukung bagi kegiatan kerja; kerja tidak terlalu melelahkan, tetapi dapat memberikan hasil yang optimal.

Terhadap pekerja upahan kiranya perlu diusahakan memperoleh imbalan yang kiranya dapat digunakan membeayai hidupnya beserta keluarganya agar dapat hidup layak, minimal memenuhi kebutuhan pokok mereka (sandang, pangan, dan papan), serta dapat menyekolahkan anaknya. Maka dalam lingkungan daerah (kabupaten, provinsi), kiranya perlu ditetapkan upah minimal dalam suatu daerah, agar para pekerja dapat mempertahankan atau bahkan meningkatkan kualitas martabat hidup mereka sebagai manusia, misalkan selain tercukupi kebutuhan pokok mereka (sandang, pangan, dan papan), 
diharapkan juga masih dapat memperkembangkan kemampuan diri mereka melalui pendidikan atau pelatihan.

Sebagai makhluk yang luhur, manusia selain memiliki otonomi dalam melakukan tindakan khasnya sebagai manusia, manusia juga cenderung untuk dapat mewujudkan dirinya sebagai manusia yang berkualitas / bernilai dalam tindakannya. Dengan pertimbangan dan kebebasan yang dimilikinya, manusia cenderung untuk memutuskan dan menghendaki tindakan yang dapat memperkembangkan dirinya sebagai manusia yang semakin berkualitas. Menurut Covey (1989: 66-67) manusia diharapkan mampu mengembangkan daya rohaniahnya tersebut, sehingga manusia tidak menjadi korban keadaan, dan tidak bersifat reaktif terhadap keadaan, tetapi mampu berperanan sebagai subjek dalam menghadapi keadaan, dan bersifat pro-aktif, yang mampu merasakan, memikirkan, mempertimbangkan, dan akhirnya menghasilkan keputusan kehendak untuk menghadapi dan menangani keadaan tersebut mewujudkan nilai-nilai kehidupan yang lebih baik dan lebih luhur.

Kerja sebagai kegiatan khas yang hanya dapat dilakukan manusia, tentu saja juga dilakukan oleh manusia dengan menggunakan pertimbangan dan kehendak untuk dapat mewujudkan kehidupan yang semakin berkualitas. Dari pembahasan di atas, dapatlah kita lihat bahwa kegiatan kerja memang memiliki berbagai macam nilai yang kiranya mampu mengembangkan manusia menjadi semakin bernilai, semakin berkualitas, yaitu nilai ekonomis, nilai pengembangan diri, nilai religius, dan nilai sosial.

Dengan memiliki kesadaran yang benar, sikap yang positif, serta terciptanya lingkungan kerja yang kondusif, diharapkan dapat mewujudkan nilai-nilai kerja tersebut di atas secara optimal. Dan sebagai dampak lebih lanjut, diharapkan dapat menghasilkan atau bahkan meningkatkan nilai kebahagiaan (bonum delectum) bagi para pekerja yang menjalaninya. 


\section{DAFTAR PUSTAKA}

Bakker, Anton. 2000. Antropologi Metafisik. Yogyakarta: Kanisius. Beding, Marcel (Penterjemah), 1984, Ensiklik Laborem Exercens dari Paus Yohanes Paulus II tentang Makna Kerja Manusia. Kanisius, Yogyakarta.

Covey, Stephen R., 1989, The Seven Habits of Highly Effective People. Fireside Simon \& Schuster Building Rockefeller Center, New York.

Groenen, Cletus \& Lanur, Alex. 1985, Bekerja sebagai Karunia (Beberapa Pemikiran mengenai Pekerjaan Manusia), Kanisius, Yogyakarta.

Kwant, Remy C. 1960. Philosophy of Labor., Dequesne University, Pittsburgh 19.

Makmurtomo, Agus \& Soekarno, B., 1989. Etika (Filsafat Moral). Jakarta: Wira Sari.

Poespoprodjo, W., 1986. Filsafat Moral, CV Remadja Karya, Bandung. Soerjanto Poespowardojo \& Bertens, K. (Red.) 1978. Sekitar Manusia (Bunga Rampai tentang Filsafat Manusia). Gramedia, Jakarta.

Sudarminta, J., 2013. Etika Umum (Kajian tentang Beberapa Masalah Pokok dan Teori Etika Normatif), Kanisius, Yogyakarta.

Wahana, Paulus. 2004. Nilai. Etika Aksiologis Max Scheler, Penerbit Kanisius, Yogyakarta.

Wahana, Paulus. "Menerapkan Etika Nilai Max Scheler dalam Perkuliahan Pendidikan Pancasila untuk Membangun Kesadaran Moral Mahasiswa" dalam Jurnal Filsafat (Fakultas Filsafat Gadjah Mada), Vol 26, No 2 (2016). 